\title{
MENEMUKAN DIMENSI LAIN DALAM DIRI MELALUI KEGIATAN MEMBACA
}

\author{
oleh \\ Febi Ramadhan \\ Tenaga pengajar Cv. International Home Schooling \\ Ramadhan.febi@gmail.com
}

\begin{abstract}
ABSTRAK
Membaca merupakan pintu gerbang masuknya peradaban dan pengetahuan ke dalam diri manusia. Sebegitu dahsyatnya pengaruh membaca sehingga mampu memotivasi banyak orang untuk membaca. Tak sedikit tokoh-tokoh pembaharu dunia yang tumbuh dan besar dari membaca. Lebih gila lagi, berbekalkan buku yang dibaca mereka bisa mengenal dan berinteraksi dengan penulis dan tokoh dunia. Namun demikian, tak sedikit pula orang yang berasumsi bahwa membaca merupakan kegiatan yang membosankan dan belum dianggap penting. Kegiatan yang seharusnya dibudayakan dan menjadi tali penghubung ilmu pengetahuan nyatanya belum mendapat tempat istimewa dikalangan masyarakat.

Permasalahan yang diangkat dalam pembahasan artikel ini adalah apa yang harus dilakukan dan cara apa yang harus ditempuh guna menyakralkan kembali kegiatan membaca di tengah permasalahan-permasalahan yang sedang menjamur saat ini. Pembahasan meliputi kegiatan mengasah potensi dasar kita yang masih tersimpan rapih di dalam alam bawah sadar, dan gambaran tokoh-tokoh besar dunia yang menemukan jati dirinya melalui kegiatan membaca.
\end{abstract}

Kata Kunci : keterampilam membaca, dimensi lain. 


\section{PENDAHULUAN}

Membaca merupakan pintu gerbang masuknya peradaban $\mathrm{d}^{\mathrm{n}}$ pengetahuan ke dalam diri manusia. Sebegitu dahsyatnya pengaruh memb sehingga mampu memotivasi banyak orang untuk membaca. Tak sed. tokoh-tokoh pembaharu dunia yar - $\cdots$ mbuh dan besar dari kegiatan membaca. Lebih gila lagi, berbek ${ }^{1}$ uku yang dibaca mereka bisa mengenal dan berinteraksi dengan $\mathrm{s}$ dan tokoh dunia. Namun demikian tak sedikit pula orang yang berasumsi bahwa membaca merupakan kegiatan yang membosankan dan belum dianggap penting. Kegiatan yang seharusnya dibudayakan dan menjadi tali penghubung ilmu pengetahuan nyatanya belum mendapat tempat istimewa dikalangan masyarakat.

Dalam sebuah pengantar buku Mendamba Indonesia yang Literat Karya Damaianti dkk , Taufik Ismail memaparkan kesimpulan bahwa keadaan yang kita hadapai saat ini luar biasa,luar biasa MENYEDIHKAN. Negara kita malas berpikir kuantitatif, dan mengabaikan kegiatan membaca dan mengarang yang akan mengantarkan anak didik ke dataran tinggi kecerdasan. Roger Farr (Damaianti dkk, 2003, hlm. 1) yang menyatakan bahwa "Reading is the heart of education", sebegitu penting Roger Farr mengartikan membaca sebagai jantung utama pendidikan, karena dengan membaca seseorang dapat menemukan ilmu pengetahuan yang sangat luas dan boleh dibilang tidak terbatas. Hal senada juga dilontarkan oleh Alwasilah (2012, hlm. 168) bahwa rapor merah literasi yang dimiliki oleh anak negeri tidak lain merupakan salah satu permasalahan yang harus segera ditemukan penawarnya.

Hingga saat ini, permasalahan yang ada masih berkutik pada persoalan lemahnya motivasi masyarakat luas untuk membaca. Mungkin mereka belum bisa memahami esensi yang sebenarnya dari membaca itu sendiri sehingga efek dahsyat yang ditimbulkan dari kegiatan membaca 
belum bisa mereka rasakan. Kita semua mengetahui prinsip-prinsip pengajaran membaca yang dikemukakan oleh Nuttal (Abidin, 2012, hlm. 156) bahwa kegiatan membaca yang pada dasarnya harus senantiasa ditunjukan guna membangun kemampuan anak berinteraksi dengan teks ternyata belum mampu mengantarkan Indonesia menuju negara yang literat. Lantas apa yang harus dilakukan dan cara apa yang harus ditempuh guna menyakralkan kembali kegiatan membaca di tengah permasalahanpermasalahan yang sedang menjamur saat ini ?

Salah-satu dari sekian banyak jawaban adalah dengan mencoba untuk membuka pikiran khalayak bahwa kegiatan membaca merupakan kegiatan yang mampu memberikan efek yang luar biasa pada diri dan kegiatan membaca dapat membawa kita ke dalam dimensi lain yang berada dalam alam bawah sadar kita dengan cara merangsang pikiran terhadap minat ataubakat seseorang. Singkatnya, dengan membaca anda dapat menemukan dimensi lain dari diri anda. Steve job berhasil mengawinkan sastra dan teknologi menjadi sebuah perangkat canggih yang saat ini menguasai pasar Gadget dunia. Sebuah bukti yang sangat nyata bahwa dengan membaca, seseorang dapat melampaui batasan yang menghalangi dirinya untuk berpikir gila.

Peran buku sebagai jembatan antara manusia dan ilmu pengetahuan juga tidak boleh dikesampingkan. Suherman (2012, hlm. 5) menjabarkan sebuah buku sebagai dunia ajaib yang menghidupkan kembali si mati dan memberikan hadiah kehidupan yang kekal kepada yang masih hidup. Buku tersebut juga menjelaskan bahwa buku berperan aktif sebagai fondasi kemajuan dan esensi pendidikan. Disitu terlihat peran buku yang begitu sentral sebagai alat komunikasi antara si pemberi kehidupan yang sebenarnya (penulis) terhadap si mati (dalam hal ini pembaca) sehingga transaksi ilmu pengetahuan dan informasi terus hidup dan setiap manusia bisa mengenal 
siapa dirinya. Di pembahasan nanti akan dipaparkan bagaimana kedudukan membaca dikaji dari psikoanalisis, stilistika, bidang agama,dan tokoh dunia yang menemukan jati dirinya melalui proses membaca.

\section{PEMBAHASAN}

Sigmund Freud menganalogikan alam sadar manusia sebagai gunung es terapung ditengah lautan, dimana es yang muncul ke permukaan yang ukurannya kecil digambarkan sebagai alam sadar manusia, sedangkan bagian bawah es yang ukurannya jauh lebih besar dan terletak dibawah permukaan digambarkan sebagai alam bawah sadar manusia. Percaya atau tidak, ternyata kita memiliki potensi besar yang tersembunyi.

Alam bawah sadar menyimpan berjuta potensi yang dimiliki setiap manusia. Jika tiap manusia memiliki potensi yang berbeda-beda dan mereka mampu mengolahnya menjadi skill atau kemampuan yang nyata, maka akan terbayang dunia yang dipenuhi oleh orang-orang jenius, ilmuan, atau tokohtokoh besar dari berbagai macam bidang.

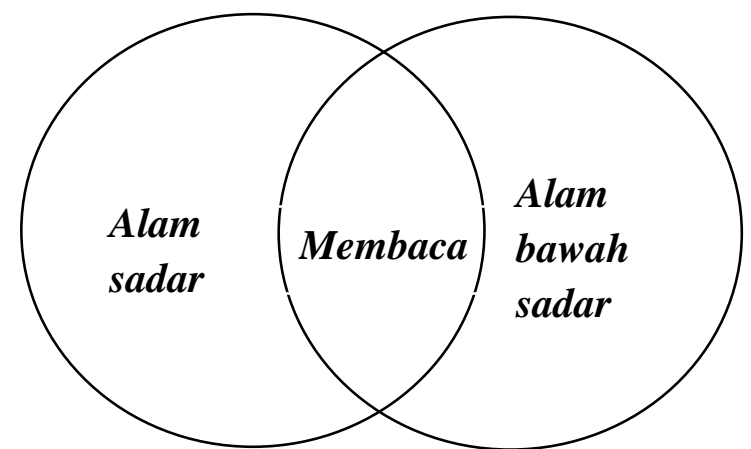

Gambar 1. Membaca sebagai penghubung antara alam sadar dan alam Bawah sadar 
Membaca adalah cara paling sederhana untuk mengasah potensi dasar kita yang masih tersimpan rapih di dalam alam bawah sadar. Informasi yang dihasilkan dari kegiatan membaca akan menghasilkan sugesti yang kuat sehingga mempengaruhi pola pikir si pembaca. Kekuatan dari sugesti inilah yang akan menghidupkan alam bawah sadar manusia dan juga mampu menghilangkan presepsi negatif tentang membaca, menemukan hal-hal yang bermanfaat, sehingga pembaca menemukan dimensi lain dalam dirinya.

Membaca juga dapat dijadikan sarana untuk melatih kerja otak manusia. Menurut Cahyo (2011, hlm. 32) otak manusia memiliki kapasitas yang sangat luas. Namun otak yang memiliki kapasitas besar tersebut tidak akan berfungsi apabila kita tidak pernah menggunakannya. Salah satu cara yang paling mudah untuk mengaktifkan kembali fungsi otak adalah membaca. Sel-sel otak akan terhubung satu sama lain saat digunakan untuk berpikir. Berarti saat membaca kita sedang menggunakan otak kita untuk berpikir. Sel-sel yang sudah terhubung akan memperkuat fungsi otak dan mempertajam daya ingat. Begitu besar pengaruh dan manfaat membaca bagi manusia, namun masih banyak orang yang belum bisa memaknai kegiatatan membaca dengan baik. Membaca juga tidak hanya ditekankan pada membaca huruf-huruf yang digabung menjadi suatu kata atau kalimat yang menghasilkan makna, namun simbol, tanda, dan lambang menjadi suatu hal yang kiranya wajib untuk dibaca. Wellek dan Warren ( Ratna, 2009, hlm. 171-172) menjelaskan bahwa simbol sebenarnya mengandung unsur kata kerja, simbol bunga mawar, pakaian warna hitam, disamping berarti bunga mawar itu sendiri, dengan warnanya yang cerah dan baunya yang harum, juga menunjukan seorang gadis remaja, wanita yang cantik, dan idaman para pemuda. Demikian halnya dengan pakaian hitam, disamping warnanya yang gelap, yang lebih penting ialah maknanya sebagai tanda berduka cita. Di Indonesia bunga mawar merupakan bunga yang populer dikalangan masyarakat, masyarakat Jepang mungkin menggunakan bunga sakura, 
masyarakat Belanda menggunakan bunga tulip, yang artinya setiap negara memiliki keragaman atau kekhasan sendiri. Hal di atas menjelaskan bahwa pemaknaan simbol sangatlah luas dan beragam apabila kita mampu membacanya dengan jeli dan cermat. Sistem simbol pun mempemudah keterpahaman antar manusia, atau justru mempersulit keterpahaman sebab proses pemahaman justru diperpanjang, dimediasi, sehingga pemahaman menjadi tidak langsung dan tersembunyi.

Jika dilihat secara sepintas, fungsi simbol dalam kaitan memaknai sesuatu mungkin terlihat sangat berbelit dan pasif namun hal tersebut justru dianggap menjadi suatu hal yang baik . Seperti yang di utarakan oleh Ritzer dan Goodman (Ratna, 2009, hlm. 173) bahwa simbol itu tidak pasif, melainkan aktif dengan cara menciptakan ulang dunia tempat aktor berpera, proses menciptakan dunia yang dimaksud ialah mengumpamakan suatu hal dengan hal yang lain atau dalam ilmu sastra dikenal dengan majas. Hal ini tentu memberikan efek yang besar bagi manusia, dengan membaca dan memahami berbagai macam simbol dan lambang yang ada akan menjadikan otak kita lebih aktif dalam mengasosiasikan suatu dan meningkatkan kemampuan berpikir .

Jika ditinjau dari segi agama, kegiatan membaca memang ada bahkan disebutkan dengan jelas dan lugas dalam agama Islam, hal ini dijelaskan secara eksplisit di dalam Al-Qur'an surat Al-Alaq ayat 1

"Bacalah dengan menyebut nama Tuhanmu yang menciptakan."

Perintah membaca dalam konteks ayat di atas memiliki banyak tafsir. Ada yang berpendapat bahwa kata baca yang dimaksud adalah membaca diri atau lebih tepatnya introspeksi, dan juga pendapat lain yang memerintahkan untuk membaca kebesaran dan keagungan Allah SWT. Namun terlepas dari itu, agama yang dianggap suci juga menaruh perhatian yang begitu besar terhadap membaca. Jika dikaji lebih dalam lagi, ayat di atas mengajarkan kita untuk senantiasa membaca diri dan membaca potensi apa yang kira-kira kita 
miliki, sehingga kita akan mengenali siapa diri kita dan untuk apa kita diciptakan dimuka bumi ini. Seorang hamba bisa mengenal tuhannya melalui pelantara kitab (buku), bisa menunaikan kewajiban dan menjauhi segala larangan yang termanifestasi dengan jelas dalam sebuah buku dan kitab (buku) tersebut hanya bisa dipahami melalui kegiatan membaca.

\section{Tokoh dunia yang menemukan jatidirinya dari membaca}

\section{Soeakrano}

Dalam buku Suherman (2012,hlm. 207-217) menjelaskan bagaimana bagaimana Soekarno menggugat imperialis yang dilakukan oleh barat dengan membaca. Masa kecilnyaia habiskan untuk membaca buku diperpustakaan, bahkan ia berkata secara psikologis atau mental ia merasa dekat dan bersahabat dengan Thomas Jefferson, karena kepada Soekarno ia menceritakan isi tentang Declaration Of Independence yang ditulisnya pada tahun 1776.

Soekarno pun merasa telah mendiskusikan persoalan dengan George Wasington. Ia juga merasa telah berdiskusi dengan Paul Revere dan memperbincangkan kesalahan-kesalahan Abraham Lincoln yang berhasil dideteksi oleh Soekarno. Ia melahap karya Karl Marx, Fredrich Engels dan Lenin.

Semangat patriotisme yang ditanam dari kegiatan membaca membuahkan sebuah gagasan bahwa negerinya harus merdeka. Berbekal pengetahuan dan semangat juang, ia mulai menyusun pledoi (pembelaan) untuk negerinya dengan judul Indonesia mengguggat yang kemudian menjadi catatan politik Indonesia. Kini nananya abadi tercatat dalam sejarah dunia, seorang pemuda yang mengubah nasibnya sendiri dan menggugat sistem penjajahan barat. 


\section{Karl Heinrich Marx}

Seorang tokoh yang gemar membaca sastra-sastra romantik dari usia muda hingga akhir hidupnya. Penganut filsafah Hegelian yang menganggap bahwa sosial, politik, agama sebagai hambatan . Ia adalah Karl Heinrich Marx, seorang pencetus ideologi kiri komunis. Yang semasa muda hingga akhir hayatnya tidak pernah lepas dari kegiatan membaca. Ketajaman intelektualnya ia dapatkan karena kegemarannya berada di British Meuseum, tempat ia mengenal sosial, politik, dan sejarah. Di tempat itu pula ia menciptakan karya besarnya yang hingga saat ini dijadikan landasan perjuangan kaum marxisme yaitu Das Kapital.

\section{Malcolm X}

Seorang yang lahir dari keluarga yang miskin di Amerika. Menjadi seorang tukang semir sepatu dan meningkat menjadi penjual serta pemakai heroin dan marijuana yang akhirnya menjadi perampok. Kerasnya kehidupan mengantarkan ia ke pintu penjara. Di penjara inilah kebiasaan barunya muncul yaitu membaca dan menulis. Tak disangka bahwa kegemarannya membaca mampu menumbuhkan semangat dan spritit untuk memahami dan menalar dunia. Berikut kutipan terkenal Malcolm X yang mampu memotivasi banyak orang di dunia.

“Dari banyak buku yang kubaca, aku merenungkan pemikiranpemikiran baru dari hal-hal yang terdapat dalam buku-buku itu, kini kusadari, dari kegemaranku membaca yang kumulai ketika masih dalam penjara, ternyata banyak membawa perubahan dalam hidupku." 
Sedikit kisah dari para tokoh empiris di atas menunjukan kepada kita bahwa mereka bisa menjadi besar karena membaca, menemukan jati dirinya karena membaca, menjadi seorang pahlawan karena membaca, seorang yang diagung-agungkan oleh para pengikutnya karena membaca. Di mata mereka buku bak layaknya candu yang bisa mengantarkan mereka kepada kenikmatan lahir dan bathin. Tidak ada alat yang mampu mengukur kepuasan mereka dalam membaca, prinsip membaca sampai akhir hayat secara tidak langsung mereka suarakan. Seperti halnya Mao, seorang tirani terkejam dari China yang tetap membaca buku disaat kondisi sekarat . Bahkan sel jeruji besi pun tamampu membendung semangat membaca Malcolm X sehingga penjara yang seharusnya ditakuti justru seolaholah menjadi perpustakaan tempat ia bisa mengenal dan menalardunia luas. Namun terlepas dari pro kontra dari tokoh di atas, tetap ada sifat yang patut kita teladani, yaitu semangat membaca yang mereka kobarkan, semangat untuk memunculkan potensi diri yang terpendam sehingga mampu mengantarkan mereka ke puncak prestasi.

\section{Penutup}

Dapat disimpulkan bahwa meningkatkan minat baca dikalangan masyarakat bisa dilakukan dengan cara menyadarkan khalayak bahwa tiaptiap diri manusia memiliki kekuatan yang luar biasa dan kita mampu menggali potensi tersebut melalui kegiatan membaca. Kekuatan dari sugesti inilah yang akan menghidupkan alam bawah sadar manusia dan juga mampu menghilangkan presepsi negatif tentang membaca, menjadikan seorang menjadi lebih humanis, memiliki sudut pandang yang luas dalam menanggapi suatu persoalan dalam kehidupan sosial, menemukan hal-hal yang bermanfaat, sehingga pembaca menemukan hal-hal baru yang harus ia cari kebenarannya. 


\section{Daftar Pustaka}

Abidin, Y. 2012. Pembelajaran bahasa berbasis pendidikan karakter. Bandung: PT. Refika Aditama.

Alwasilah, A. Chaedar. 2012. Pokoknya rekayasa literasi.

Bandung: Kiblat.

Cahyo, A. 2011. Berbagai cara latihan otak dan daya ingat dengan menggunakan ragam media audio visual.Yogjakarta:DIVA Press.

Damaianti,V.S, dkk. 2003. Mendamba Indonesia yang literat.

Bandung: Jurusan Pendidikan Bahasa dan Sastra Indonesia FDBS Universitas Pendidikan Indonesia.

Hernowo. 2003. Quantum reading.

Bandung: MLC.

Ratna, N. Khuta. 2009. Stilistika :Kajian puitika, sastra, dan budaya. Yogyakarta: Pustaka Pelajar.

Suherman. 2012. Mereka besar karena membaca. Kabupaten Bandung: Literate Publishing. 